\title{
Regulation of Agricultural Trade and Its Implications in the Reform of the CAP. The Continental Products Case Study
}

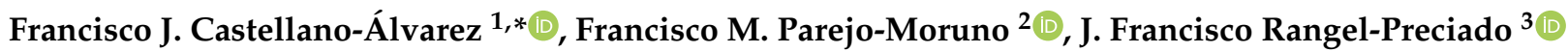 \\ and Esteban Cruz-Hidalgo 4 (D) \\ 1 Department of Economics, Faculty of Business, Finance and Tourism, University of Extremadura, \\ 10071 Cáceres, Spain \\ 2 Department of Economics, Faculty of Economic and Business Sciences, University of Extremadura, \\ 06006 Badajoz, Spain; fmparejo@unex.es \\ 3 University Center of Plasencia, Department of Economics, University of Extremadura, 10600 Plasencia, Spain; \\ jfrangelp@unex.es \\ 4 Department of Economics, Faculty of Law, University of Extremadura, 10071 Cáceres, Spain; ecruzh@unex.es \\ * Correspondence: fcocastellano@unex.es; Tel.: +34-690-683-971
}

\section{check for}

updates

Citation: Castellano-Álvarez, F.J.;

Parejo-Moruno, F.M.;

Rangel-Preciado, J.F.; Cruz-Hidalgo,

E. Regulation of Agricultural Trade

and Its Implications in the Reform of the CAP. The Continental Products

Case Study. Agriculture 2021, 11, 633. https:/ / doi.org/10.3390/agriculture 11070633

Academic Editor:

Gioacchino Pappalardo

Received: 15 June 2021

Accepted: 2 July 2021

Published: 7 July 2021

Publisher's Note: MDPI stays neutral with regard to jurisdictional claims in published maps and institutional affiliations.

Copyright: (c) 2021 by the authors. Licensee MDPI, Basel, Switzerland. This article is an open access article distributed under the terms and conditions of the Creative Commons Attribution (CC BY) license (https:// creativecommons.org/licenses/by/ $4.0 /)$.

\begin{abstract}
The evolution of the Common Agricultural Policy (CAP) has been conditioned by a number of factors. Among them is the so-called external aspect of the CAP on which this work focuses, being the main objective to analyze the relationship between the evolution of the CAP and the negotiations leading to the liberalization of international agricultural trade, which were held within the General Agreement on Tariffs and Trade (GATT) and the World Trade Organization (WTO). In the same way, we also consider the consequences for European agricultural foreign trade derived from the commitments assumed by the European Union (EU) in those two negotiating forums. To achieve these objectives, this research proposes two working lines: first, a literature review for better understanding how international agricultural trade has been regulated since the end of the Second World War to the present, and second, a research effort to know the possible implications that said regulation have had for the evolution of European agricultural foreign trade. In this latter case, the issue is addressed through an empirical analysis using two of the main specialized statistical databases in international trade: EUROSTAT and COMTRADE. The results of the research show that, as the changes introduced by the CAP reforms have been consolidated (based on the trade commitments assumed by the EU), there has been a gradual decrease in the share of European exports in the international markets for continental products.
\end{abstract}

Keywords: agricultural protectionism; export subsidies; Uruguay and Doha rounds; Common Agricultural Policy

\section{Introduction}

For decades, the CAP has been one of the best examples of a truly common policy for all countries participating in the European integration process. A good example of its relevance is that, at the beginning of the 2000s, after the long reform process that began in the 1980s, the resources allocated to this policy still accounted for $50 \%$ of the Community budget. Among others, García Álvarez-Coque and Compés [1] or Bonete [2] have studied the factors that conditioned the evolution of the CAP, differentiating between: (a) internal factors, such as budgetary limitations, the imbalances fostered between different crops, farms and territories, and the surpluses generated over decades in many of the typically continental areas of production; and (b) external factors, such us the repeated pressures exerted by many of our trading partners regarding European agricultural protectionism and the effects that some of the measures applied by the CAP have had on international agricultural markets. 
Regarding this second category of factors, García Álvarez-Coque, Jordán and Martínez [3]; Compés, García Álvarez-Coque and Baviera [4]; or Flores [5] link the evolution of the CAP with the commitments that the EU was forced to assume in the Uruguay and Doha Rounds. Studying the reasons why both issues are related and the consequences that derive from this for European agricultural foreign trade constitutes the central objective of this research. To achieve it, this research — and this is its main novelty-proposes to take an intermediate approach between those who focus on the study of the CAP and those who analyze the international agricultural trade from very different perspectives.

Some examples of this diversity of approaches are the contributions of Sadoulet and De Janvry [6], who study the impact that liberalization of agricultural trade (linked to the Uruguay Round negotiations) has had on the poorest countries; this question constitutes an important research line within which it is possible to highlight many works as Brandão and Martin [7], Goldin and Van der Mensbrugghe [8], Ingco [9], Hathaway and Ingco [10], Harrison, Rutherford and Tarr [11]. Aksoy and Beghin [12] or Koning and Pinstrup [13] address the same issue but expanding their analysis to the negotiations carried out in the context of the WTO. Baier and Bergstrand $[14,15]$ resort to econometric models to try to calculate the effects that free trade agreements have on the increase in trade flows. Without neglecting the liberalization of agricultural trade, Coyle et al. [16] pay attention to the factors that condition agricultural demand and supply, as well as the evolution of transport costs. Along these lines, the contributions of Rimmer and Powell [17], Serrano and Pinilla [18] or Granfield et al. [19] have been oriented to the analysis of the food demand function.

Leaving aside the analysis of the effects of liberalization of agricultural trade, Pinilla [20], Aparicio, Pinilla and Serrano [21], or Serrano and Pinilla [22] resort to a historical perspective to study the evolution of international agricultural trade. Baiardi, Bianchi and Lorenzini [23] study the factors that condition the evolution of agricultural exports and predict an increase in competition between emerging and developed countries in the case of processed agricultural products.

Within the analysis of international trade, another research line refers to the study of fair trade. Wielechowski and Roman [24] conclude that this type of trade focuses mainly on tropical products from underdeveloped countries, especially from African countries. Even sharing some of the criticisms received for this practice, the aforementioned authors consider fair trade as an interesting initiative that deserves to be promoted. Regarding the least developed countries, and based on the Heckscher-Ohlïn model, Maseland and De Vaal [25] analyze the circumstances where the adoption of a particular trade policy (being free trade policy, protectionist trade policy, or another policy based on the practice of fair trade) may be more suitable. Arnot, Boxall and Cash [26], based on the study of the coffee trade, show that fair trade consumers have less sensitivity to price increases than other consumers. For his part, Henderson [27] is very critical on the fair-trade practice, to the point that he defines it as unfair and unproductive.

The relationship between international trade and environment is a matter of controversy among authors. In this issue, there are basically two positions: those who consider that international trade harms the conservation of the planet's natural resources [28-31] and those who defend that international trade contributes to conserving the environment [32-36]. Along with the economic perspective, in this matter, there is abundant research that, using a legal approach, analyzes the consequences that free trade agreements can have for the conservation of the environment and natural resources in the less developed countries [37].

With its approach, this research aims to transcend those other analyses that, from a purely sectoral and descriptive perspective, study the evolution of the trade of very diverse agricultural products. Along these lines, works can be cited on the trade in garlic (Parejo-Moruno, Rangel-Preciado and Cruz-Hidalgo [38]; García-Marchante [39]), fresh fruits and vegetables (Chebil and Briz-Escribano [40], Cook [41]), table olives (Parejo and Rangel [42];, De Pablo and Giacinti [43]), pears (De Pablo, Pires and Giacinti [44]), cherries (García, De Pablo and Giacinti [45]), strawberries and red fruits (De Pablo et al. [46]); olive 
oil (De Pablo et al. [47]), apples (Giacinti [48]), almonds (De Pablo, García, and Giacinti [49]) and citruses (Giacinti [50]). In addition, as analyzed in the methodology section, this research uses the European sphere as a field of analysis, thereby obtaining a broader vision than that which could be derived from the study of any aspect related to the CAP in a specific country or geographical area (Volkov et al. [51], Namiotko and Baležentis [52], Pomianek [53], Mroczek [54]).

After this introduction, the second section of this work tries to explain how, to what extent, and why the long postwar period in which the agrarian question was kept outside the GATT negotiations, the Marrakesh and the Hong Kong Conferences conditioned then, and still condition today, the evolution of the CAP. The third section details the methodological questions of the research and the four sections, based on the case study of continental products, and tries to relate the scenario described in the first point, with the evolution of European agricultural foreign trade, focusing its attention on the analysis of two variables: (a) the participation of European exports within the world market and (b) the evolution of the trade balance. Finally, a discussion heading is incorporated, and the most relevant conclusions of the research are presented.

\section{The Regulation of International Agricultural Trade and Its Implications for the CAP}

\subsection{The Agrarian Exception in the Postwar Stage}

Whoever wants to refer to the origin of the regulation of international trade, as it is understood today, must go back to the International Conference on Trade and Employment held in Havana in 1946. The countries attending this summit were very aware of the disastrous effects that the protectionist policies of the interwar period had wrought. Those policies led to the collapse of international trade and, therefore, the worsening of the crisis itself throughout the 1930s. In the new postwar scenario, the countries gathered in Havana (which were none other than the main exporting powers) sought to agree on new trade rules that would avoid repeating the mistakes of the past. One of the conclusions of that meeting referred to the creation of the International Trade Organization (ITO) which, together with the International Monetary Fund (IMF) and the International Bank for Reconstruction and Development (IBRD, now the World Bank), would constitute the three main exponents of the new international economic order after the Second World War. However, that organization was never created, and in its place, in 1947, twenty-three countries participating in the Havana Summit signed the GATT, through which it was intended to fulfill part of the tasks assigned to the frustrated ITO.

Despite the fact that, at first, it was considered provisional, the GATT turned out to be what Prieto and Esteruelas [55] (p. 138) consider the "largest commercial agreement known in history". Until the creation of the WTO in 1995, the GATT would play a decisive role in the regulation and liberalization of international trade. During the half-century from 1948 to 1995, the GATT held eight rounds of negotiations. With the exception of the last of them, the Uruguay Round (1986-1994), in which trade in agricultural products was the subject of intense negotiations, in the seven previous rounds, the commitments in favor of the liberalization of international trade focused primarily on industrial products.

In the years following the end of World War II, in which the GATT held its first rounds, the exclusion of agricultural products from them could be justified based on two reasons: (a) the food shortage that afflicted the countries that had participated in the war and, as a consequence, the absence of competition between agricultural exporters and (b) the bargaining power of the advanced countries, more interested in liberalizing trade in manufactures and continuing to protect their agriculture from competition from developing countries. It was in the early 1960s, when the agricultural stimulus policies promoted by the different countries began to reverse the situation, and when the implementation of the Common Agricultural Policy generated significant misgivings in the main exporters of agricultural products [56], that a certain debate was fostered regarding the trade of this type of goods. However, in general terms, the discussions raised hardly served to ratify the agrarian exceptionality and the peculiarities of this sector within international trade. 
Contributing to this was also the fact that the criticisms made by the United States (US) (one of the countries most hostile to the incipient CAP) were undermined by its own actions in agrarian matters. US protectionism with respect to trade in agricultural products dates back to 1955, the year in which that country requested several exceptions in agricultural matters within the GATT (known in GATT jargon as "waivers"). These exceptions would allow the US to apply a series of protectionist measures but, indirectly, they would also legitimize other countries such as Japan and the then European Economic Community (EEC), to follow their example. The ultimate consequence of this would be the marginalization of agricultural products from the GATT negotiations.

In the second half of the 1950s, at the beginning of the European integration process, the difficulties in the supply of food that the European population had suffered during and after World War II were still very present. This contributed to the fact that agriculture had a great relevance in the Treaty of Rome and in the definition of its objectives (increase in productivity and agricultural income, stability of agricultural markets, guarantee of supply of agricultural products at reasonable prices). The Stresa Conference held in July 1958 marks a milestone in the formulation of the CAP and of some principles (market unity, Community preference, and financial solidarity) that could not have been the same without the American precedent and the agrarian exceptionality within the GATT. As a consequence of the decisions adopted during the long period leading up to its articulation culminated, the CAP would be characterized by its dual status as protectionist and productivist. From the beginning of the 1960s, the CAP represented a profound transformation of an agriculture that was modernizing and intensifying, achieving a notable increase in production. At the end of the 1970s, the "infernal logic" [57] inherent in a policy of guaranteed prices that was not related to the functioning of the markets had generated enormous surpluses and considerable costs. The elimination — via exports — of those not only aggravated their impact on the Community budget but also involved multiple conflicts with other food-producing countries [58].

Despite the fact that, in the so-called Dillon Round of the GATT, the US and the EEC had agreed on the external aspect of the CAP, the confrontations between them (and with the rest of the exporting countries of agricultural products) were constant. These countries denounced agricultural protectionism and export subsidies as distorting the prices of agricultural products in international markets. Thus, during the 1980s, the CAP was the subject of continuous debate: in October 1981, the Commission analyzed the problems generated by the CAP in its report Guidelines for European Agriculture [59]; in 1983, its first adjustments were made, with the aim of limiting production and reducing costs; just two years later, the CAP Green Paper [60] insisted on the need to tackle surpluses, and in 1988, within the "Delors Package", new production control instruments were proposed based on the application of automatic stabilizers, reduction of guaranteed prices, and substitution of surplus crops for others that were not in surplus. During this period, the different reforms carried out had perverse effects on the logic used by farmers, who responded to the narrowing of their margins with an increase in their production.

Although, as the CAP was consolidated, it became a source of external conflicts, and despite the fact that, in its reform process, it was always difficult to define the extent to which some factors or others had influence, the two timid reforms approved in the 1980s were due not so much to the external pressure exerted by the rest of the GATT signatory countries, but rather to internal problems, especially agricultural surpluses and the enormous budgetary cost associated with them.

\subsection{Trade in Agricultural Products within the Uruguay Round}

The Uruguay Round began in 1986 with the Declaration of Punta del Este, which included the liberalization of trade in agricultural products as one of the main issues under negotiation [61,62]. Although the countries belonging to the EEC were not the only ones that supported their agriculture, in the negotiations involving the liberalization of agricultural trade, the CAP, and the protectionism implicit in it, they were the object of 
virulent criticism from various fronts, of which the CAIRNS Group and the US need to be highlighted $[63,64]$.

The CAIRNS Group was made up of Australia, Argentina, Brazil, Canada, Colombia, Chile, the Philippines, Hungary, Indonesia, Malaysia, New Zealand, Thailand, and Uruguay. These countries were characterized by their ability to export agricultural products at competitive prices and by their rejection of some of the CAP practices, since they caused the collapse of agricultural prices in the international market. In contrast to previous negotiations, the relevance of the CAIRNS Group was an important novelty of the Uruguay Round. These countries lobbied for the liberalization of agricultural trade and even conditioned progress in talks on trade in services and intellectual property rights on the assumption of specific commitments by the EEC in agricultural matters [64].

The US position, at least, can be described as paradoxical since, although it was a country that protected its farmers (and very much so), in these negotiations, it had no qualms about uniting with the CAIRNS Group in raising criticisms against European protectionism [65]. To understand the US position, it is necessary to bear in mind the ability that, in its rejection of the CAP, the US had to lead criticism, from one person to another, towards those Community protection measures that had the least effect on its own agrarian policy.

In the Uruguay Round, the debate regarding trade in agricultural products was not so much about being for or against protectionism; rather, the differences focused on the types of measures used to articulate protectionist policies and the intensity with which certain countries implemented them. As Gómez [66] points out, in agrarian matters, countries that apply protectionist policies can resort to various instruments such as: (1) price support policies, which could take the form of border protection measures, export subsidies, or maintenance of internal prices; (2) income maintenance policies, such as direct aid, that seek to maintain farmers' incomes without altering the formation of prices in the markets; and (3) other support measures such as tax exemptions, aid for the commercialization of products, agricultural insurance, environmental incentives, etc.

In the Uruguay Round, countries undertook to clearly define their agricultural support measures and once defined, to classify them into three possible categories, or "boxes" (according to the term used by the GATT).

- The "Amber Box" would be made up of prohibited aid that had to be reduced by the agreed percentages due to its distorting effects on agricultural markets. In this group would be the internal price maintenance policy.

- The "Blue Box" would include direct aid partially unrelated to production, as well as programs aimed at limiting it, such as set asides.

- Within the "Green Box", the aid allowed to agriculture would be counted because it did not have distorting effects on international trade. This category would include aid for agricultural research, rural development, natural disasters, programs aimed at protecting the environment, etc.

The definition and classification of measures to support agriculture and their compatibility with the agreements that regulate international agricultural trade are a matter of enormous importance in the evolution of the CAP. Despite the opposing positions, none of the parties questioned the existence of internal aid [67] as long as it did not alter the formation of international agricultural prices or stimulate production. However, in other elements of support for agriculture, such as the various border protection instruments or export subsidies [68], the negotiations were much more complicated. To reach an agreement, the EEC would have to make important commitments in both areas.

Regarding border protection, most of the GATT signatories demanded that the EEC replace it with tariffs (tariffication process) and, once these were set, begin their progressive reduction. This would subject European production to greater international competition; European agricultural prices would start to approach world prices, and ultimately, this would force a reduction in intervention prices. 
Although the CAP entailed both a decrease in imports and an increase in exports, it was this latter aspect that aroused the most criticism given that, as a consequence of European export subsidies, world market prices of the most characteristic products of continental agriculture (those most protected by the CAP) were kept at lower levels than they would have had in the absence of these measures; most studies placed these lower prices in a range of between 2 and 10\% [69]. This is the reason why agricultural exporters denounce unfair competition from export subsidies. The situation becomes even more complicated if, as happened until the early 1980s, thanks to these subsidies, European producers increase their participation in international markets to the detriment of those other countries that consider themselves efficient agricultural producers. Continental products (cereals, sugar, beef, dairy products and derivatives) are the most benefited by this type of aid.

As in any negotiation, the initial positions of the two sides were on the extremes: the EEC rejected any modification in the regulation of agricultural trade that would alter the design of the CAP, while most of the GATT signatory countries-led by the US and the CAIRNS Group-demanded, within a maximum period of ten years, the total abolition of those forms of aid to agriculture that would distort international trade.

Regardless of how far the starting positions were, the truth is that the notoriety that agrarian trade acquired in the Uruguay Round and the important demands that most of the countries maintained with respect to it caught offside an EEC whose agrarian policy was still characterized by its dual status as protectionist and productivist. Among the arguments used by the EEC in defense of its agrarian policy were food security, the implicit peculiarities of agricultural activity, and the relevance that the exercise of it had for the conservation of space and the maintenance of the population in the rural environment. However, European isolation and its limited room for maneuver were evident [64]. In December 1990, the consequence of this was the failure of the Brussels Summit with which it was hoped to finalize the negotiations of this eighth GATT Round.

After the failure of the Brussels Summit, the European Commission prepared a report on the evolution of the CAP [70] in which the need to undertake a profound reform of the same was raised. Despite the fact that, to justify this reform, said document gave little relevance to the external pressures from the Uruguay Round and instead emphasized the internal problems from the CAP itself (agricultural surpluses, decrease in the agricultural workforce, stagnation of agricultural income, concentration of aid in a small number of farms), Josling [71] considers the McSharry Report as the European response to the pressure exerted by the majority of the GATT signatory countries. The Commission then proposed the first major reform of the CAP, known as the McSharry reform, which would imply the reduction of intervention prices in some of the main Common Market Organizations (CMOs) (cereals, oilseeds, legumes, dairy, and beef) and, as a consequence, a gradual equalization between Community and international prices, which would lead to the reduction of export subsidies. The Commission would partially offset these measures with the creation of direct aids "apparently" unrelated to production.

The measures adopted show an evident coherence with the negotiating scenario outlined in the Uruguay Round: the reduction of guaranteed prices meant reducing the Community aid computed in the Amber Box and, although its disconnection from production is more than debatable, the compensation of this measured with the creation of direct aid meant allocating their cost to the Blue Box. Although it is true that the creation of the Blue Box was a "compromise" solution to reach a final agreement, it is also true that the agreement limited the existence of that fund until 2003. This first major reform of the CAP allowed for progress in the Uruguay Round negotiations. In November 1992, in the so-called Blair House Agreement, the US and the EEC agreed on a position regarding trade in agricultural products that allowed for the culmination of eight years of negotiations in what, ultimately, would be the last GATT Round. The Marrakesh Agreement (1994), with which the Uruguay Round culminated, obliged the EEC to transform border protection 
instruments into tariffs and to assume specific commitments both in reducing these and in export subsidies [72,73].

However, while it is true that, in export subsidies, the commitments did go a bit further (and referred to both monetary amounts and quantities exported), in terms of tariff reductions and domestic support for agriculture, the final agreement fell far short of the expectations of agricultural exporters, with the added handicap that the developed countries, in the supposed fulfillment of their commitments, used tactics contrary to the spirit of the agreement, such as "dirty tariffication" or the setting, as the basis for the reductions of years in which the aid or tariffs had been higher. These practices would be strongly denounced by the less developed agricultural exporters within the Doha Round.

\subsection{Background to the Millennium Round}

The great contribution of the Uruguay Round was the full incorporation of agricultural trade into the GATT negotiations and the commitment assumed by the participants to treat its results not as a point of arrival but as a point of departure for new negotiations that, starting in 1999, they should continue to advance in the liberalization of agricultural trade [74-76].

Aware that the Marrakesh Agreement was temporary and that the launch of a new negotiating round would pose new challenges for European agriculture, at the end of the 1990s, the European authorities approved the Agenda 2000 [77]. This document represented a new reform of the CAP with which the European Commission intended to anticipate the demands that would derive from a new round of negotiations. As with the McSharry reform, in the reform proposed by Agenda 2000, a multitude of factors converged. In addition to the relevance of the imminent start of a new negotiating round, the Commission itself also referred to other factors such as the desire for Community agriculture to continue to gain competitiveness and benefit from the increase in world demand for food and the need to avoid the appearance of a new problem of agricultural surpluses, given the forthcoming incorporation of the Eastern European countries.

In line with the McSharry reform, Agenda 2000 supposed a further reduction in guaranteed prices for some of the most surplus products (cereals, dairy, and beef) and partially offset the effects that this reduction could have on farm incomes with an increase in direct aid. These measures would reduce aid from the Amber Box in favor of other aid that, by virtue of what was agreed to in the Uruguay Round, would be attributed to the Blue or Green Boxes. However, the main novelty of the aforementioned document would be the Commission's commitment to the concept of multifunctionality as the argument differentiating the European agricultural model from that of other countries in favor of the liberalization of agricultural markets. However, Massot [78] (p. 10) pointed out that, far from developing this idea, in Agenda 2000 "multifunctionality was born [...] as a simple ideological alibi to oppose our main commercial rivals in the Millennium Round of negotiations." In fact, his plea in favor of the uniqueness of European agriculture would be one of the main discussions within the agrarian chapter in the Doha Round.

\subsection{The Doha Round and Its Development Agenda}

Faced with the misgivings that the globalization process had generated among broad sectors of society, and which became apparent with the protests of all kinds of social groups at the failed Seattle Conference (1999), the declaration of the launch of the Doha Round (2001) paid special attention to justifying the need to continue advancing in the liberalization of world trade. The argument chosen for this centered on the development of the poorest countries; hence, the agenda and the challenges highlighted in its initial declaration were classified as the "Development Agenda." The consequence of this interest by the aforementioned countries would be the relevance that, in the course of the negotiations, trade in agricultural products should acquire and the reduction of those instruments and protection policies maintained by the developed countries with respect to them. In the same way that the CAIRNS Group had a great relevance in the Uruguay Round, on 
this occasion, the group known as G-20 would channel the demands of those countries that, being competitive in world agricultural markets, saw their productions damaged by developed countries that were reluctant to fulfill the commitments made in the Uruguay Round [79].

Created within the Ministerial Conference that the WTO held in Cancun in 2003, the G-20 acquired such relevance that, according to Amorim [80] (p. 15), "it has changed the geopolitics of international agricultural negotiations" reducing the excessive role that the two great agrarian superpowers, the US and the EU, had traditionally maintained in them. In fact, the genesis of this group is linked to the firm opposition of its member countries to the strategy followed in the aforementioned conference by the European and American negotiators who, at dawn on the same day as the closing of the meeting, in an effort to reissue the Blair House Agreement which had brought them such good results in the Uruguay Round, announced that it had not been possible to reach an agreement on agrarian matters but that there was a consensus for continuing negotiations in another series of sectors coinciding with their interests. A number of countries, most prominently Brazil, India, and China, considered this announcement as an attempt by these two powers to mutually cover for their deficiencies in agrarian matters by rejecting the aforementioned pact and the possibility of advancing in the negotiations to liberalize the trade of other sectors until an agrarian agreement was reached. Those countries that blocked the agreement between the US and the EU would unite around the so-called G-20 to vindicate the interests that the least developed countries had in terms of agricultural foreign trade. This group included ten Latin American countries (Argentina, Bolivia, Brazil, Chile, Cuba, Guatemala, Mexico, Paraguay, Uruguay, and Venezuela), five African countries (Egypt, Nigeria, South Africa, Tanzania, and Zimbabwe), and six Asian countries (China, the Philippines, India, Indonesia, Pakistan, and Thailand).

For this group of countries, it seemed clear that the importance given in the initial declaration of the Doha Round to the liberalization of trade in agricultural products constituted more of an institutional declaration than an unequivocal commitment of the developed countries; "It was more of a rhetorical pose than reality" [5] (p. 165).

Despite the failure of Cancun and without renouncing the argument of agrarian singularity, the European Commission continued on the path of the McSharry and Agenda 2000 reforms, delving into those points where the design of the CAP was most distant from the commitments that, in the context of such negotiations, would have to be assumed. In July 2002, the European Commissioner for Agriculture took advantage of the need for a midterm review of the CAP to present a series of proposals that went beyond what a midterm evaluation job would have required. In fact, what is known as Fischler's proposal [81], which finally materialized in Regulation (EC) No. 1782/2003 [82] (European Council, 2003), involved even more profound changes than those made in 1999.

The arguments used for this new reform were not new; they had already appeared in Agenda 2000: social legitimation of aid to agriculture, conservation of the environment, extension of farms, the need to continue adapting aid to agriculture to the international scene, etc. However, this reform deepened the previous ones [83] and marked the culmination of the CAP's evolution from a policy of intervention in the markets to an income policy based on direct aid characterized by (a) its disconnection from production, so that the aid could not be blamed for distorting the functioning of agricultural markets; (b) its conditionality on the fulfillment of good agricultural and livestock practices and the care of the environment; and (c) the modulation of aid in farms with annual subsidies of more than 5000 euros. The decoupling of the aid and its conditionality had an unambiguous intention: its imputation to the Green Box and reinforcement of the arguments in favor of the existence of the Blue Box beyond the transitory nature with which, at the beginning, it was approved (and was to expire 2003). In fact, extending the existence of the aforementioned Blue Box and defending the multifunctionality of its agriculture would be the main demands of the European negotiators. 
Figure 1 represents the evolution of aid linked to production in the most representative continental products. Espinosa [84] does not hesitate to link this remarkable transformation of agricultural spending with the development of the negotiations inherent in the Doha Round. The Fischler reform led to a drastic reduction in production-related aid, in such a way that, in 2006, this type of aid barely represented a fifth of what it was two years earlier.

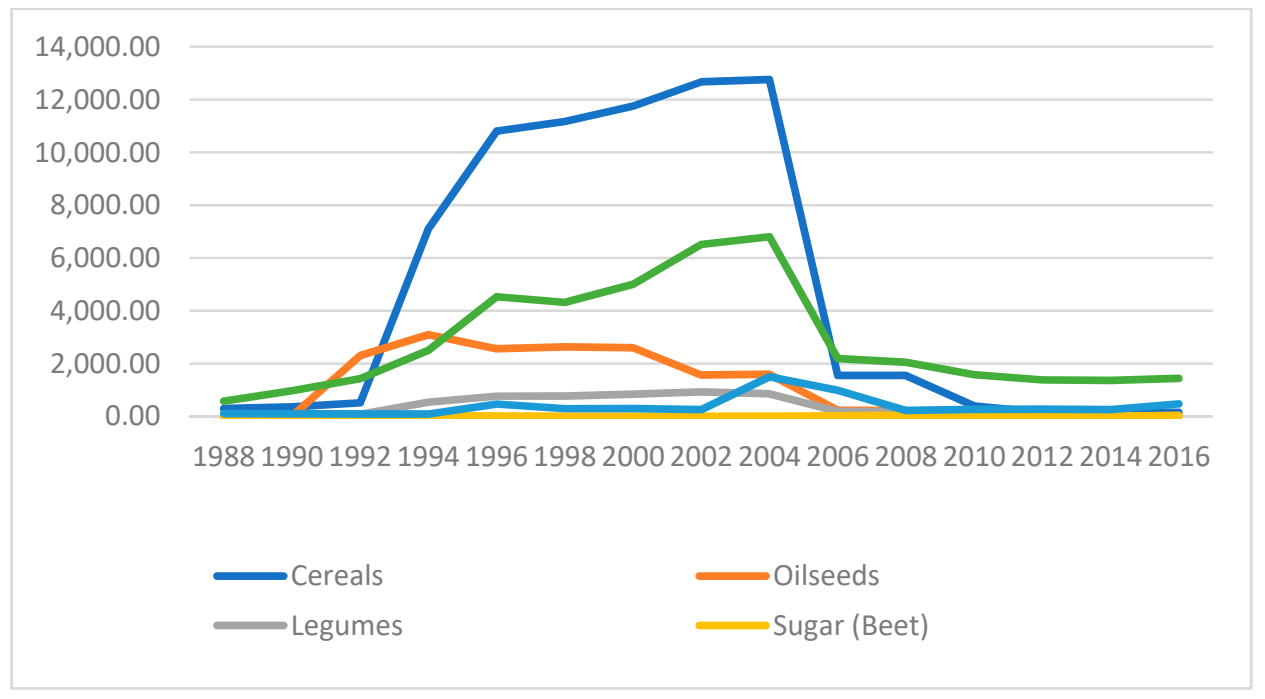

Figure 1. Production aid for continental products 1988-2016 (millions of euros). Source: own elaboration based on data obtained from EUROSTAT.

After the launch of the Doha Round and the failure of the Cancun Conference, Hong Kong (2005) would be the setting in which a new WTO Conference would be held which, this time, would imply new commitments in the field of agricultural trade. According to Blandford [85], they would once again emphasize three issues: (a) domestic support policies for the primary sector, (b) access barriers to the markets of developed countries, and (c) elimination of export subsidies. On this occasion, after the reforms carried out, the EU was in a position to assume new commitments in the aforementioned matters [86] such as (1) reducing internal aid based on its amount and reviewing those included in the Green and Blue Box, to guarantee its correct allocation to them; (2) applying higher tariff reductions to products with higher tariffs; and (3) ending export subsidies in 2013.

The commitments inherent in the Hong Kong Conference and the need to analyze the results achieved by the midterm Review of the CAP (2003) gave rise, first, to the Communication of the Commission Preparing to check the reform of the CAP [87] and, later, to Regulation 73/2009 [88] (European Council, 2009), which aimed to update the Fischler reform based on the following measures: (a) reduction or elimination of intervention prices in products still being maintained (precisely the continental ones, the object of study), (b) total decoupling of crops in those countries that had been allowed a progressive decoupling of aid and replacement of the historical criteria used for its calculation by a uniform aid depending on the area, (c) adaptation of the conditionality criteria to the reality of agricultural holdings, and (d) extension of the modulation applied to higher amounts of aid.

Figure 2 shows the evolution of European production of continental products. As can be seen, the CAP reform process and the gradual untying of aid and production seem to have influenced this last variable. As has been studied, those affected by the first, timid CAP reforms responded to them by increasing their production to compensate for the narrowing of their margins; that trend continued until the mid-1990s. From then on, the CAP progressively lost its productivist orientation to become a policy of income decoupled from production. This implies the stagnation of agricultural production. Even being valued at current prices, the 2010 production level was lower than that of 1996. 


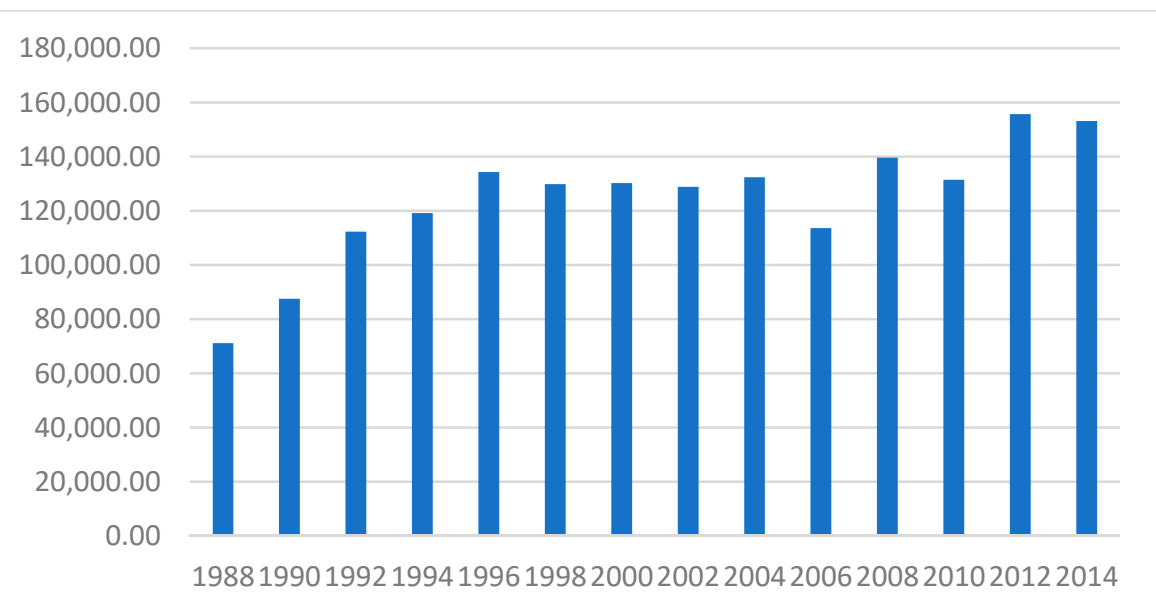

Figure 2. European production of continental products EU (15) (millions of euros, current prices). Source: own elaboration based on data obtained from EUROSTAT.

Since the Hong Kong Conference (2005), the only developments in agricultural trade that have occurred within the WTO were within the Ministerial Conferences of Bali (2013) and Nairobi (2015) and did not represent notable changes in the regulation of agricultural trade.

For its part, the Communication on the future of food and agriculture [89] marked the beginning of a new process to review the CAP. Among the arguments used to justify this new reform were the need to simplify its management $[90,91]$, increase national subsidiarity, strengthen social acceptance of aid to agriculture [92], and guarantee the production of food in a more sustainable way in a context of combating climate change [93]. Unlike previous reform processes, on this occasion, after the long reform process started in 1992, the adaptation of the CAP to international trade agreements will no longer be one of the arguments used to justify its reform.

\section{Materials and Methods}

\subsection{Methods for the Literature Review}

The literature review exercise carried out has been comprehensive and consistent with the research objectives. From the various digital bibliographic databases, an attempt has been made to synthesize the main lines of research currently existing on international trade in agricultural products, paying special attention to the literature that has addressed the Uruguay Round negotiations and the commercial and customs aspects derived from them. The voluminous bibliography analyzed comes, for the most part, from prestigious publications and therefore from renowned researchers on international trade, although attention has also been paid to monographs published in paper format that should be kept in account for the differential vision that they contribute to the bibliographic debate on the subject dealt.

\subsection{Geographical Scope and Time Horizon of the Research}

Regarding the temporal scope of the research, the analysis of the regulation of international trade dates back to the end of the Second World War and practically continues to the present day. In this period, the European integration project has undergone a continuous territorial expansion that makes it impossible to take the European sphere as a reference since, after successive enlargements, the evolution of European foreign trade has varied, not depending on the policies applied, the competitiveness of production, or the international agreements adopted, but rather because the base that would be taken as a reference would be broader. Therefore, it is essential that the basis of the analysis be homogeneous and refer to the same group of countries for the full duration. 
In the 1980s there were two enlargements of the then EEC; since then, the integration process has been made up of twelve partners. However, taking this group of countries (EU12) as the object of analysis is only partially compatible with the statistical series available in EUROSTAT. Although these series start in 1988, since 1995 (after the integration of Austria, Finland and Sweden) that database has not offered aggregated information for the EU-12. To overcome this inconvenience, the data of the EU-12 for the period 1988-1994 will be used and, from 1995, the reference will be the EU-15, for which EUROSTAT does offer aggregated data. However, in 1995, the countries that joined the integration process only accounted for 5\% of the European Final Agricultural Production (FAP), or 3\% of their exports, so these issues do not affect the validity of the results of the investigation.

\subsection{Agricultural Production as Object of Analysis}

Within continental production, a series of crops such as herbaceous crops (cereals, oilseeds and protein crops), beef, sugar, or milk and its derivatives deserve to be highlighted. Historically, these products have had a greater relevance in the FAP of the founding countries of the EEC. In fact, authors such as Cejudo [94] (p. 143) criticize the territorial imbalances generated by the CAP, given "the different productive specialization of the regions and the disparate support given to the various agricultural productions, prioritizing continental ones over Mediterranean ones". To support his proposals, the cited author studied the relevance that both types of products had within the Community FAP and the aid they received from the CAP in the mid-1980s. As a consequence of their greater competitiveness within international agricultural markets, export refunds for Mediterranean production were an "anecdote" compared to continental ones. The elimination of export refunds, given the distortion they generate on the functioning of international agricultural markets, would be one of the great workhorses of those who criticized the protectionist bias of the CAP. Therefore, continental products represent a paradigmatic example of the consequences for Community agriculture to face the challenge of liberalizing its foreign trade as a result of the negotiations held within the GATT and the WTO.

\subsection{Statistical Sources Used}

The research objectives include the analysis of two specific questions related to the evolution of agricultural foreign trade. The analysis of these issues requires resorting to different statistical bases so that, to analyze the participation of European exports in the world market, the statistics of the United Nations Department of Economic and Social Affairs are used (https:/ / comtrade.un.org/data/). The United Nations database allows for obtaining the exports of all the countries under analysis (reporters) for the entire world market (partners) within the same search. However, the United Nations statistics have some limitations: they do not provide aggregate information for a specific group of countries (for example, EU-15), nor do they differentiate between intra- and extra-Community trade.

For its part, the EUROSTAT database is used to analyze the evolution of the European trade balance (https:/ / ec.europa.eu/eurostat/data/database). This does allow for the creation of aggregates for the joint consultation of a group of countries. Another interesting feature of this database is the difference between intra- and extra-Community trade (the latter will be the data taken as a reference in this part of the research).

\section{Results}

\subsection{Share of European Exports within World Markets}

Figure 3 compares the evolution of world and European exports. As can be seen, at the beginning of the series studied, both variables remained at similar levels, making a gap that began to be pronounced in the early 2000s. These trends could corroborate the criticisms of those authors who, already at that time, denounced the gradual expulsion of European productions from international markets [95]. 


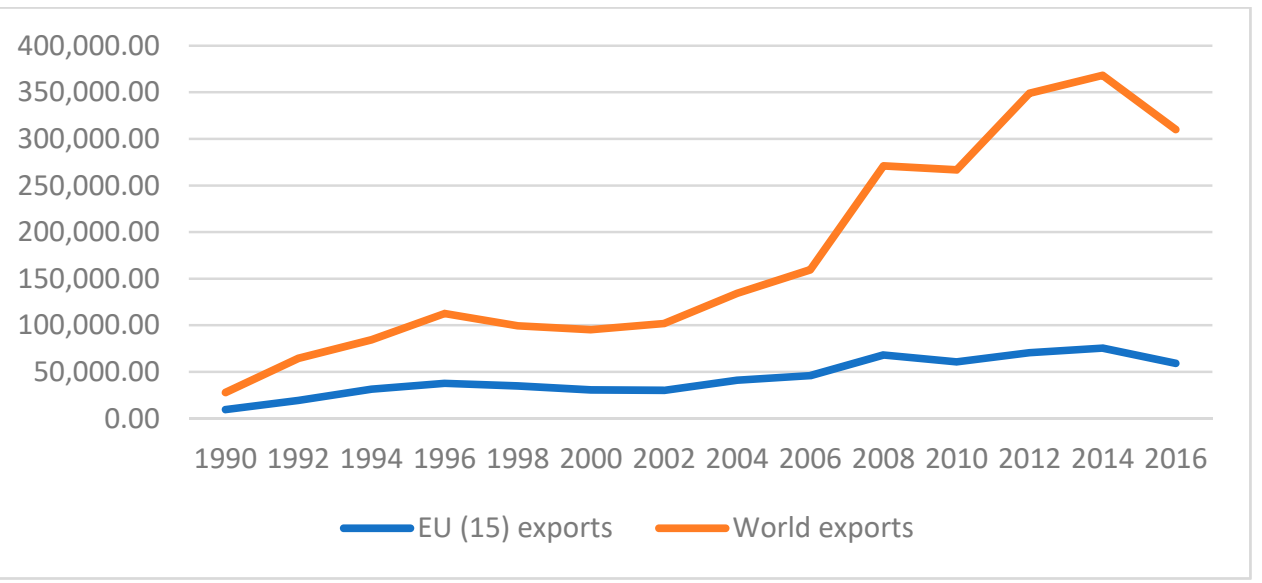

Figure 3. World and EU exports (15) continental products (millions of dollars, current prices). Source: own elaboration from data obtained from UN Comtrade Database.

The trends pointed out by the previous figure are confirmed by Figure 4, which shows the unequivocal decrease in the share of European exports in world markets. In the series analyzed, the year in which the Uruguay Round ended (1994) was the year in which European continental production achieved a greater share of international markets. Since then, its relative importance has gradually decreased. The decline in the relative importance of European exports contrasts with the growing importance of G-20 exports. For their part, although with certain fluctuations, CAIRNS Group countries have been able to maintain their participation in the aforementioned markets throughout the period studied.

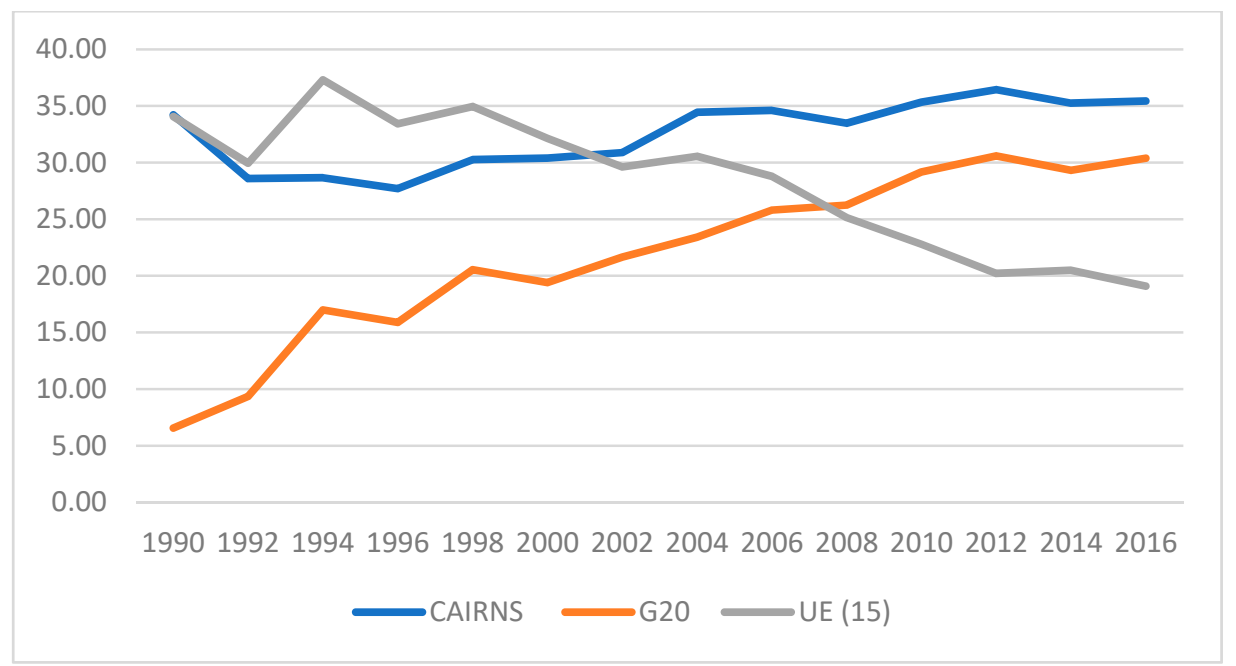

Figure 4. Share of EU (15), CAIRNS and G20 in world exports of continental products. Source: own elaboration from data obtained from UN Comtrade Database.

Although the decline in importance of European exports occurred in all products, there are differences with respect to its intensity and the market share of each of the productions in world markets. As shown in Figure 5, at the end of the series analyzed, European exports of dairy products and their derivatives still accounted for $49.34 \%$ of the world market; at the opposite end would be the oilseeds that barely represented $5 \%$ of world exports at the time. 


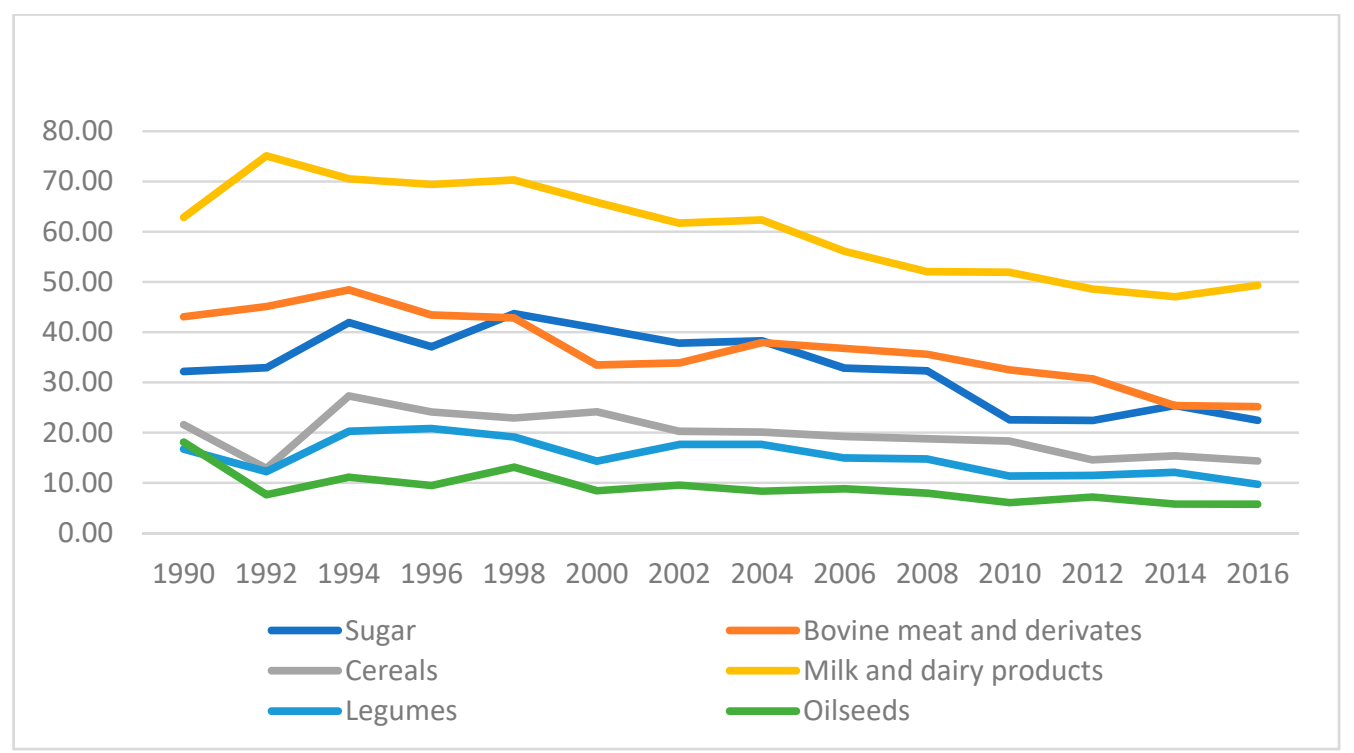

Figure 5. European share in world exports of continental products. Source: own elaboration from data obtained from UN Comtrade Database.

\subsection{Foreign Trade Balance of Continental Agricultural Products}

As shown in Figure 6, in the recent evolution of the foreign trade balance of the continental products, it is possible to differentiate two periods. In a first stage (1988-2000), there were no significant changes in the trends of imports and exports, while in a second period (2000-2016), the trade deficit increased due to the increase in imports. This fact inevitably relates to the stagnation of European production since the mid-1990s (Figure 2). Despite the fact that, in the mid-2000s, as a consequence of the growth in world demand, European exports also enjoyed an appreciable increase, this was not enough to avoid the increase in the deficit. Even valued at current prices, exports in 2004 were lower than in 1994.

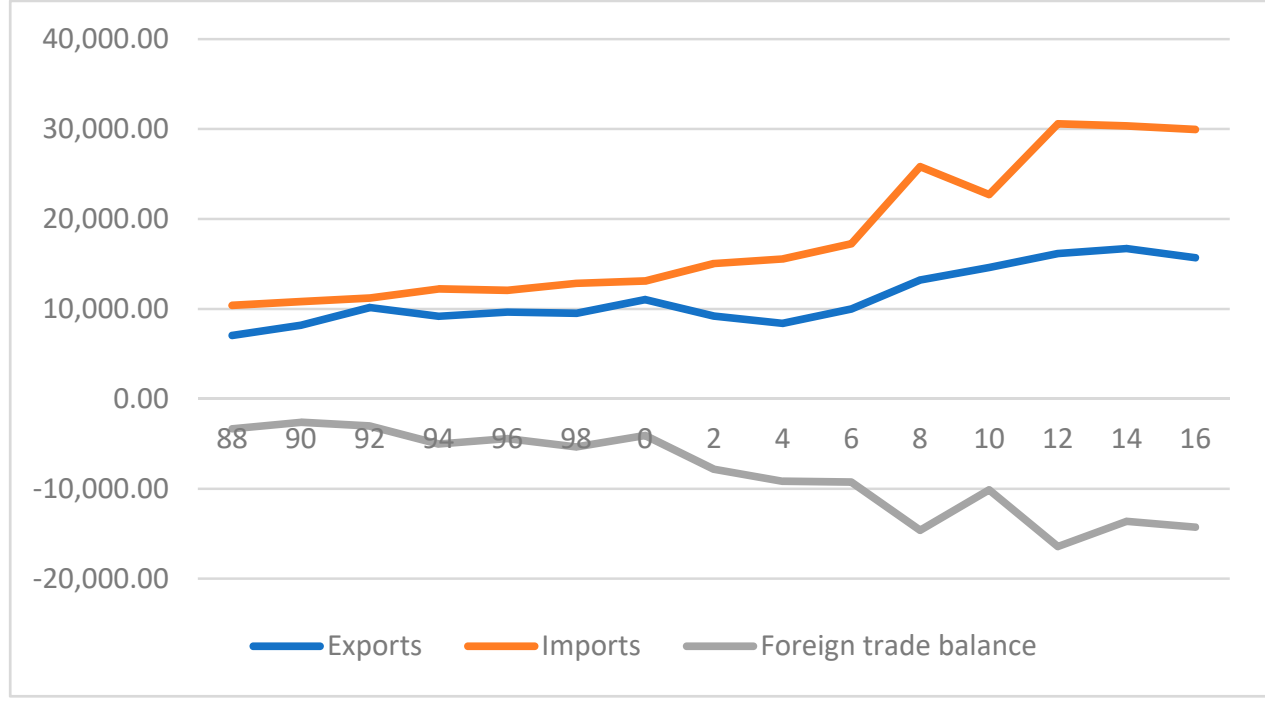

Figure 6. Evolution of foreign trade in continental products (millions of euros, current prices). Source: own elaboration based on data obtained from EUROSTAT.

However, as Figure 7 shows, from the second half of 2000, there was an improvement in the commercial balance of dairy products and, with the exception of legumes, a deterio- 
ration in the commercial balance of the rest of the products with very notable cases such as cereals and oilseeds. Throughout all these stages (1988-2016), in absolute terms, the trade deficit for continental products overall quadrupled.

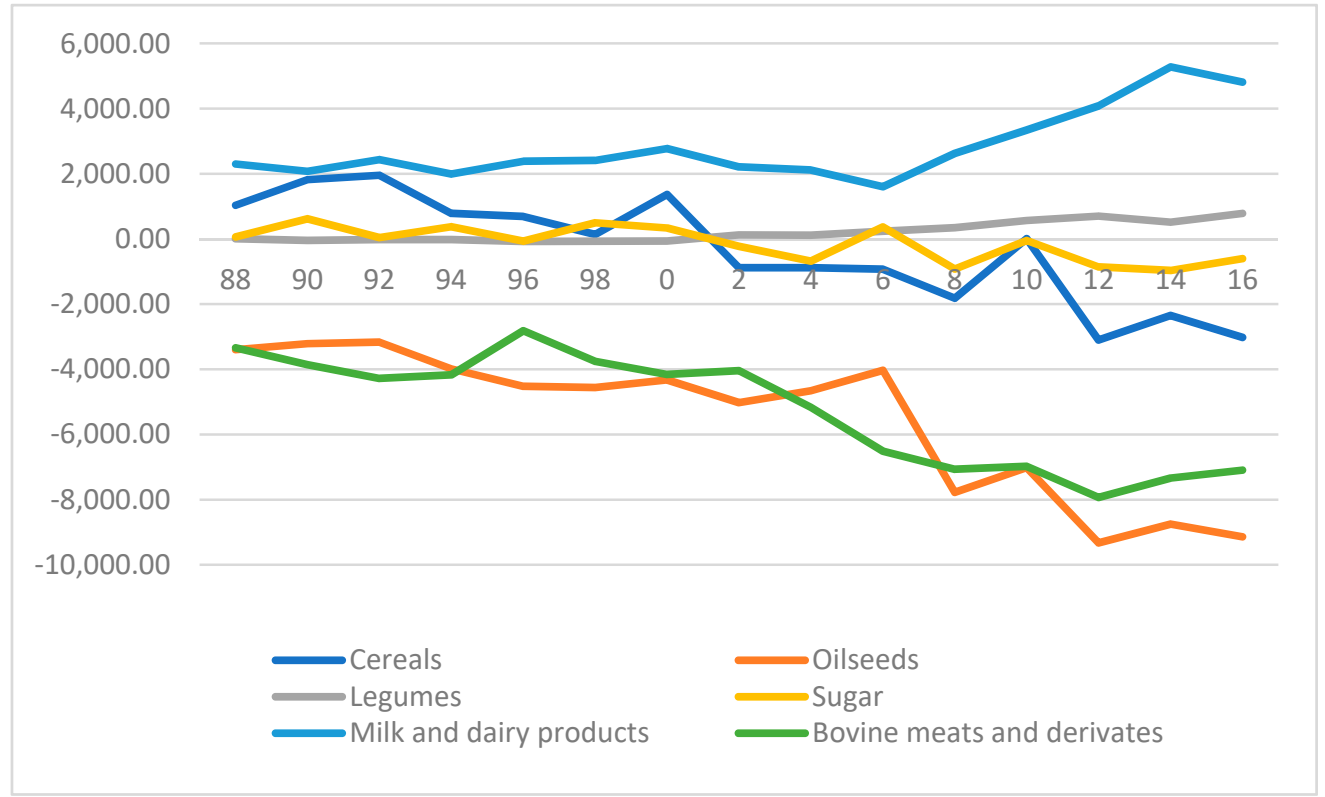

Figure 7. Foreign trade balance for continental products (millions of euros, current prices). Source: own elaboration based on data obtained from EUROSTAT.

\section{Discussion}

Henderson [27] criticizes the practice of fair trade and defends that the best way to favor the growth of underdeveloped countries and increase the income of their agricultural producers is by ending the planet's trade barriers; in other words, by promoting the liberalization of international agricultural trade. Therefore, there would be a coincidence between the mentioned author and the postulates defended by the CAIRNS and the G-20 in the negotiations of the Uruguay and Doha rounds. In fact, Figure 4 shows how, as the commitments inherent to the aforementioned negotiations and the CAP reforms are implemented, the participation in international agricultural trade of the countries that constitute the aforementioned pressure groups increases.

However, other authors show us how these supposed benefits derived from the agricultural trade liberalization cannot be extrapolated in a generic way to a reality as heterogeneous as that of the least developed countries. In this sense, Sadoulet and De Janvry [6] conclude that the expulsion of European products from international agricultural markets has different consequences for less developed countries: while competitive agricultural exporters linked to the CAIRNS and the G-20 benefit from this expulsion, others, the poorest countries, which require the importation of many of the typically continental products to cover their food needs, suffer the consequences of the increase in international agricultural prices. In this line, authors such as Ignco [9] or Anderson and Neary $[96,97]$ think that, among the reasons why these countries are not able to benefit from the liberalization of agricultural trade is not (or not as the main reason) the protectionism of the developed countries but their own behavior, as well as their inability to improve the functioning of their economies and address the necessary reforms that allow them to benefit from the opportunities generated by trade liberalization.

Therefore, in line with the works of Heyl et al. [37], the loss of market share of European products shown by this research, and denounced by Lamo de Espinosa and Champourcin [95], not only harms European producers, but also seems to have negative consequences on the poorest countries of the world. Paradoxically, as Tangermann pointed 
out, some of the most criticized measures of European agricultural protectionism, such as export subsidies, put downward pressure on international agricultural prices [69], from which the poorest countries benefited.

\section{Conclusions}

Although the evolution of the CAP depends on many different factors and it is difficult to define the extent to which each of them influences it, this research studies the interrelationship between the evolution of the negotiations held with the purpose of regulating international agricultural trade and the CAP reforms. This interrelation between both variables existed even in the period in which agricultural trade was excluded from the negotiations held within the GATT, and it is key to explaining the design and principles on which that policy was based at the beginning of the 1960s.

The commitments made in the Uruguay Round and their transfer to the first major reform of the CAP represent a milestone. At that point, a process began in which, progressively, the importance of those policies and measures aimed at intervention in the markets would diminish, in favor of other aid that, gradually, was disconnected from production and reinforced its conditionality. This evolution of the CAP towards a decoupled income policy seems to have conditioned the European FAP: even valued at current prices, the 2010 production of the continental products analyzed was lower than that of 1996.

At the same time that production stagnated, the participation of European exports in the international market declined, and its trade balance deteriorated. Between 1988 and 2016, the trade deficit in continental products quadrupled, even as dairy products and their derivatives enjoyed a trade surplus that actually increased throughout the period analyzed. Those who benefit most from the lower European participation in world markets are the group of countries that make up the so-called G-20. In 1990, this group of countries barely accounted for $6 \%$ of world exports of the products under analysis, while in 2016 their share was around $30 \%$.

A correct interpretation of the research results requires taking into account its limitations. These are derived from methodological aspects. Specifically, those are referred to the type of products under study and the chosen territorial scope. Regarding the former, it must be considered that this research analyzes the European agricultural foreign trade for a series of products, and its conclusions do not have to be extrapolated to other agricultural products. The second limitation refers to the territorial scope. When taking as a reference the countries that make up the EU (12) or the EU (15), this study does not take into account the exports of Eastern European countries that, in successive enlargements, joined the EU. Some of these countries are prominent world exporters of some typically continental products (such as cereals), so even maintaining a European analysis, the broadening of the territorial base could alter the final conclusions of the study.

A future line of research could contrast the results of this study with the analysis of Mediterranean products (a priori, much more adapted to the competition of international agricultural markets and less protected by the CAP). This could provide a broader vision of European agricultural external trade and its balance with third countries.

Anyway, this research relates issues that are frequently studied separately, such as the design and evolution of the CAP, international trade negotiations, and the empirical analysis of community agricultural foreign trade. In this sense, evaluating the approach used, this work can be considered as a contribution regarding the analysis of the effects that protectionism can have on agricultural production and its competitiveness, as well as the challenges and opportunities that for the group of countries that make up the international economy the liberalization of agricultural trade represents.

Author Contributions: Conceptualization, F.J.C.-Á., F.M.P.-M., J.F.R.-P. and E.C.-H.; investigation, F.J.C.-Á., F.M.P.-M., J.F.R.-P. and E.C.-H.; methodology, F.J.C.-Á., F.M.P.-M., J.F.R.-P. and E.C.-H.; writing-review \& editing, F.J.C.-Á., F.M.P.-M., J.F.R.-P. and E.C.-H. All authors contributed equally to this work. All authors have read and agreed to the published version of the manuscript. 
Funding: The dissemination of this work has been possible thanks to funding granted by the Ministry of Economy, Science and Digital Agenda of the Junta de Extremadura and by the European Regional Development Fund of the European Union to the research groups DESOSTE and GEHE through the aids with references GR18052 and GR18140.

Conflicts of Interest: The authors declare no conflict of interest.

\section{References}

1. García Álvarez-Coque, J.M.; Compés, R. Las reformas de la Política Agrícola Común en la Unión Europea ampliada: Implicaciones económicas para España. Papeles Econ. Esp. 2005, 103, 230-244.

2. Bonete, B. Condicionamientos Internos y Externos de la PAC; MAPA: Madrid, Spain, 1994.

3. García Álvarez-Coque, J.M.; Jordán, J.; Martínez, V. El modelo europeo de agricultura y los acuerdos internacionales. Papeles Econ. Esp. 2008, 117, 227-242.

4. Compés, R.; García Álvarez-Coque, J.M.; Baviera, A. La reforma de la OCM de frutas y hortalizas. Evaluación de la propuesta de la Comisión Europea. Inf. Comer. Esp. 2007, 2910, 19-30.

5. Flores, J. Las reformas de la PAC y la Ronda Doha. Econ. Mund. 2006, 15, 155-177.

6. Sadoulet, E.; De Janvry, A. Agricultural trade liberalization for the low-income countries: A general equilibrium-multimarket approach. Am. J. Agric. Econ. 1992, 74, 268-280. [CrossRef]

7. Brandão, A.S.; Martin, W.J. Implications of agricultural trade liberalization for the developing countries. Agric. Econ. 1993, 8 , 313-343. [CrossRef]

8. Goldin, I.; Van der Mensbrugghe, D. The Uruguay Round: An Assessment of Economywide and Agricultural Reforms. In The Uruguay Round and the Developing Economies; Martin, W., Winters, A., Eds.; World Bank: Washington, DC, USA, 1995.

9. Ingco, M. Has agricultural trade liberation improved welfare in the least-developed countries? Yes. In Policy Research Working Paper, 1748; The World Bank: Washington, DC, USA, 1997.

10. Hathaway, D.; Ingco, M. Agricultural Liberalization in the Uruguay Round. In The Uruguay Round and the Developing Economies; Martin, W., Winters, A., Eds.; World Bank: Washington, DC, USA, 1995.

11. Harrison, G.; Rutherford, T.; Tarr, D. Quantifying the Uruguay Round. In The Uruguay Round and the Developing Economies; Martin, W., Winters, A., Eds.; World Bank: Washington, DC, USA, 1995.

12. Aksoy, M.; Beghin, J.C. Global Agricultural Trade and Developing Countries; The World Bank: Washington, DC, USA, 2005.

13. Koning, N.; Pinstrup, P. Agricultural Trade Liberalization and the Least Developed Countries; Springer: Dordrecht, The Netherland, 2007.

14. Baier, S.; Bergstrand, J.H. Do free trade agreements actually increase members' international trade? J. Int. Econ. 2007, 71, 72-95. [CrossRef]

15. Baier, S.; Bergstrand, J.H. The growth of world trade: Tariffs, transport costs and income similarity. J. Int. Econ. 2001, 53, 1-27. [CrossRef]

16. Coyle, W.; Gehlar, M.; Hertel, T.; Wang, Z.; Yu, W. Understanding the determinants of structural change in world food markets. Am. J. Agric. Econ. 1998, 80, 1051-1061. [CrossRef]

17. Rimmer, M.T.; Powell, A.A. An implicitly directly additive demand system. Appl. Econ. 1996, 28, 1613-1622. [CrossRef]

18. Serrano, R.; Pinilla, V. Causes of world trade growth in agricultural and food products, 1951-2000: A demand function approach. Appl. Econ. 2010, 42, 3503-3518. [CrossRef]

19. Granfield, J.; Eales, J.; Hertel, T.; Preckel, P. Model selection when estimating and predicting consumer demands using international cross section data. Empir. Econ. 2003, 28, 353-364. [CrossRef]

20. Pinilla, V. El comercio exterior en el desarrollo agrario de la España contemporánea: Un balance. Hist. Agrar. Rev. Agric. Hist. Rural 2001, 23, 13-38.

21. Aparicio, G.; Pinilla, V.; Serrano, R. Europe and the international trade in agricultural and food products, 1870-2000. In Agriculture and Economic Development in Europe Since 1870; Lains, P., Pinilla, V., Eds.; Routledge: London, UK, 2009; pp. 52-75.

22. Serrano, R.; Pinilla, V. New directions of trade for the agri-food industry: A disaggregated approach for different income countries, 1963-2000. Lat. Am. Econ. Rev. 2014, 23, 1-22. [CrossRef]

23. Baiardi, D.; Bianchi, C.; Lorenzini, E. Food competition in world markets: Some evidence from a panel data analysis of top exporting countries. J. Agric. Econ. 2015, 66, 358-391. [CrossRef]

24. Wielechowski, M.; Roman, M. The essence of fair trade and its importance in the world economy. Oeconomia 2012, 11, 47-57.

25. Maseland, R.; De Vaal, A. How fair is Fair Trade? Economist 2002, 150, 251-272. [CrossRef]

26. Arnot, C.; Boxall, P.; Cash, S. Do Ethical Consumers Care About Price? A Revealed Preference Analysis of Fair Trade Coffe Purchases. Can. J. Agric. Econ. 2006, 54, 555-565. [CrossRef]

27. Henderson, D. Fair Trade is Counterproductive and Unfair. Econ. Aff. 2008, 28, 68-71. [CrossRef]

28. Pendrill, F.; Persson, U.M.; Godar, J.; Kastner, T. Deforestation displaced: Trade in forest-risk commodities and the prospects for a global forest transition. Environ. Res. Lett. 2019, 14, 055003. [CrossRef]

29. Jiborn, M.; Kander, A.; Kulionis, V.; Nielsen, H.; Moran, D.D. Decoupling or Delusion? Measuring Emissions Displacement in Foreign Trade. Glob. Environ. Chang. 2018, 49, 27-34. [CrossRef] 
30. Aichele, R.; Felbermayr, G. Kyoto and Carbon Leakage: An Empirical Analysis of the Carbon Content of Bilateral Trade. Rev. Econ. Stat. 2015, 97, 104-115. [CrossRef]

31. Henders, S.; Persson, U.M.; Kastner, T. Trading forests: Land-use change and carbon emissions embodied in production and exports of forest-risk commodities. Environ. Res. Lett. 2015, 10, 125012. [CrossRef]

32. Xu, Z.; Li, Y.; Chau, S.N.; Dietz, T.; Li, C.; Wan, L.; Zhang, J.; Zhang, L.; Li, Y.; Chung, M.G.; et al. Impacts of international trade on global sustainable development. Nat. Sustain. 2020, 3, 964-971. [CrossRef]

33. Brandi, C.; Schwab, J.; Berger, A.; Morin, J.-F. Do environmental provisions in trade agreements make exports from developing countries greener? World Dev. 2020, 129, 104899. [CrossRef]

34. Martínez-Zarzoso, I.; Oueslati, W. Do Deep and Comprehensive Regional Trade Agreements Help in Reducing Air Pollution? Int Environ. Agreem. Polit. Law Econ. 2018, 18, 743-777. [CrossRef]

35. Bastiaens, I.; Postnikov, E. Greening up: The Effects of Environmental Standards in EU and US Trade Agreements. Environ. Polit. 2017, 26, 847-869. [CrossRef]

36. Frey, C. Tackling Climate Change through the Elimination of Trade Barriers for Low-Carbon Goods: Multilateral, Plurilateral and Regional Approaches. In Legal Aspects of Sustainable Development: Horizontal and Sectorial Policy Issues; Mauerhofer, V., Ed.; Springer International Publishing: Cham, Switzerland, 2016; pp. 449-468.

37. Heyl, K.; Ekardt, F.; Roos, P.; Stubenrauch, J.; Garske, B. Free Trade, Environment, Agriculture, and Plurilateral Treaties: The Ambivalent Example of Mercosur, CETA, and the EU-Vietnam Free Trade Agreement. Sustainability 2021, 13, 3153. [CrossRef]

38. Parejo-Moruno, F.M.; Rangel-Preciado, J.F.; Cruz-Hidalgo, E. La inserción de China en el mercado internacional del ajo: Un análisis descriptivo, 1960-2014. Econ. Agrar. Recur. Nat. 2020, 20, 75-99. [CrossRef]

39. García-Marchante, J. La hortofruticultura protegida: El caso del ajo morado de Las Pedroñeras. In Los Productos con Indicación Geográfica en el Sistema Agroalimentario Español: Tradición y Modernidad; Institución Fernando El Católico: Zaragoza, Spain, 2012; pp. $25-41$.

40. Chebil, A.; Briz-Escribano, J. Función de exportación hortícola española. ICE Rev. Econ. 2000, 788, 79-85.

41. Cook, R. Tendencias internacionales en el sector de frutas y hortalizas frescas. Rev. Esp. Econ. Agrar. 1997, 181, 183-208.

42. Parejo, F.M.; Rangel, J.F. El mercado mundial de aceituna de mesa (1990-2015). Reg. Sect. Econ. Stud. 2016, 16, 127-146.

43. De Pablo, J.; Giacinti, M.A. Aceituna de mesa: Mapa de competitividad internacional. Rev. Frutic. 2012, 24, 112-119.

44. De Pablo, J.; Pires, J.; Giacinti, M.A. Comercio internacional de la pera. Rev. Frutic. 2015, 45, 124-143.

45. García, T.; De Pablo, J.; Giacinti, M.A. Competitividad internacional de la cereza. Rev. Frutic. 2019, 70, $108-125$.

46. De Pablo, J.; García, T.; Giacinti, M.A.; Giacinti, N.S. Competitividad internacional en fresa y frutos rojos de España. Rev. Frutic. 2016, 51, 52-80.

47. De Pablo, J.; García, T.; Giacinti, M.A.; Giacinti, N.S. Competitividad internacional del aceite de oliva. Rev. Frutic. 2017, 56, 142-169.

48. Giacinti, M.A. Radiografía mundial del negocio de manzanas. Precios en alza: ¿sólo una burbuja o es una tendencia? Frutic. Prof. 2007, 167, 27-38.

49. De Pablo, J.; García, T.; Giacinti, M.A. Comercio internacional de almendras. Rev. Frutic. 2016, 49, $190-219$.

50. Giacinti, M.A. Radiografía del negocio de cítricos del hemisferio sur en Europa. Frutic. Prof. 2007, 165, 19-26.

51. Volkov, A.; Baležentis, T.; Morkūnas, M.; Streimikiene, D. Brexit and EU Common Agricultural Policy: The possible consequences for Lithuania. Econ. Sociol. 2019, 12, 328-344. [CrossRef]

52. Namiotko, V.; Baležentis, T. Dynamic efficiency under investment spikes in Lithuanian cereal and dairy farms. Econ. Sociol. 2017, 10, 33-46. [CrossRef] [PubMed]

53. Pomianek, I. Socio-economic development of agricultural problem areas in Poland. Econ. Sociol. 2014, 7, 218-235. [CrossRef] [PubMed]

54. Mroczek, R. Red meat sector after accession of Poland to the EU. Econ. Sociol. 2009, 2, 69-76. [CrossRef]

55. Prieto, J.R.; Esteruelas, L. El GATT y el comercio internacional de productos agrarios. Rev. Estud. Agro-Soc. 1989, 148, 137-170.

56. Sancho, R. El GATT y la reforma estructural de la CEE. Rev. Estud. Agro-Soc. 1991, 155, 131-143.

57. Moyano, E. La política agraria en el proceso de integración europea. Rev. Fom. Soc. 1998, 53, 47-68. [CrossRef]

58. Etxezarreta, M.; Cruz, J.; García, M.; Viladomiú, L. La Agricultura Familiar, ante las Nuevas Políticas Agrarias Comunitarias; MAPA: Madrid, Spain, 1995.

59. European Commission. Guidelines for European Agriculture. COM (81) 608 Final, SUPPLEMENT 4/81; Bulletin of the European Communities: Luxembourg, 1981; pp. 63-107.

60. European Commission. Perspectives for the Common Agricultural Policy. COM (85) 333; Bulletin of the European Communities: Brussels, Belgium, 1985.

61. General Agreement on Tariffs and Trade. Draft Ministerial Declaration on the Uruguay Round. MIN (86)/w/19. Available online: www.wto.org (accessed on 15 May 2021).

62. Castillo, J.A. Esbozo de una explicación de la Ronda Uruguay. Rev. Estud. Agro-Soc. 1991, 155, 79-103.

63. Tanner, C. Agricultural Trade Liberalization and the Uruguay Round. Aust. J. Agric. Econ. 1996, 40, 1-35.

64. García Álvarez-Coque, J.M. Las propuestas de liberalización del comercio mundial agropecuario: Una aproximación cualitativa. Rev. Estud. Agro-Soc. 1991, 155, 11-40. 
65. Kein, G.; Pustay, M. Progresos en el GATT: Papel de Estados Unidos y de los nuevos bloques comerciales. Rev. Estud. Agro-Soc. 1991, 155, 70-78.

66. Gómez, P. Políticas de ayuda y protección a la agricultura: Su tratamiento en el GATT. Rev. Estud. Agro-Soc. 1991, 155, 105-129.

67. Martín, M.A. La agricultura de Estados Unidos frente a la europea en la liberalización del comercio agrario. Rev. Estud. Agro-Soc. 1991, 155, 55-67.

68. San Juan, C. La Ronda Uruguay del GATT: La dimensión internacional. Rev. Estud. Agro-Soc. 1991, 155, $193-198$.

69. Tangermann, S. La influencia de terceros países sobre la Política Agrícola Común. Rev. Estud. Agro-Soc. 1987, 140, $109-131$.

70. European Commission. Evolution and Future of the Common Agricultural Policy. COM (91) 100. Supplement 5/91; Bulletin of the European Communities: Luxembourg, 1991.

71. Josling, T. La PAC reformada y el mundo industrializado. Rev. Estud. Agro-Soc. 1993, 165, 57-78.

72. Millet, M. La Regulación del Comercio Internacional: Del GATT a la OMC; Colección de Estudios Económicos de La Caixa; La Caixa: Barcelona, Spain, 2001.

73. Millet, M. La PAC y las negociaciones comerciales internacionales. In Política Agraria Común: Balance y Perspectivas; García, J.L., García, M.J., Eds.; Colección de Estudios Económicos de La Caixa; La Caixa: Barcelona, Spain, 2005; pp. $154-181$.

74. García Álvarez-Coque, J.M. ${ }^{\text {; }}$ Valdés, A. Las tendencias recientes del comercio mundial de productos agrarios: Interdependencia entre flujos y políticas. Rev. Econ. Agrar. 1997, 18, 9-30.

75. Rodrigo, F. Para entender la OMC y la Ronda Doha. Econ. Exter. 2006, 37, 28-36.

76. Caviedes, A. La ordenación del comercio internacional de productos agropecuarios en la OMC. ICE 2014, 3056, 53-62.

77. European Commission. Agenda 2000. Por una Unión más Fuerte y más Amplia. COM (97) 2000 Final. Supplement 5/97; Bulletin of the European Communities: Luxembourg, 1997.

78. Massot, A. La PAC, entre la Agenda 2000 y la Ronda del Milenio: ¿A la búsqueda de una política en defensa de la multifuncionalidad agraria? Rev. Estud. Agro-Soc. Pequeros 2000, 188, 9-66.

79. Mahía, R.; De Arce, R.; Escribano, G. La protección arancelaria al comercio agrícola mundial diez años después de la firma del acuerdo sobre agricultura de la Ronda Uruguay. Inf. Comer. Esp. 2005, 820, 223-233.

80. Amorim, C. El G-20 en la Ronda Doha. Econ. Exter. 2006, 37, 15-20.

81. European Commission. Midterm Review of the Common Agricultural Policy. Communication from the Commission to the Council and Parliament. COM (2002) 394; OJEU; Publications Office of the European Union: Luxembourg, 2002.

82. European Council. Regulation 1782/2003, of 29 September 2003 Establishing Common Rules for Direct Support Schemes under the Common Agricultural Policy; OJEU; Publications Office of the European Union: Luxembourg, 2003.

83. Massot, A. La reforma de la Política Agraria Común de junio de 2003: Resultados y retos para el futuro. ICE 2004, $2817,35-55$.

84. Espinosa, E. El comercio internacional de productos agrarios. Econ. Exter. 2006, 37, 21-27.

85. Blandford, D. Liberalización del comercio agrario, globalización y economías rurales. ICE 2002, 803, $23-32$.

86. Rubio, M. ${ }^{a}$ R. La liberalización del comercio agrícola internacional. ICE 2009, 2975, 6-15.

87. European Commission. Preparing for the CAP Reform Checkup. Communication to the European Parliament and the Council. COM (2007) 722 Final; OJEU; Publications Office of the European Union: Luxembourg, 2007.

88. European Council. Regulation (EC) No. 73/2009, of 19 January 2009, Establishing Common Rules for Direct Support Schemes for Farmers under the Common Agricultural Policy and Establishing Certain Support Schemes for Farmers, Amending Regulations (EC) No. 1290/2005, (EC) No. 247/2006, (EC) No. 378/2007 and Repealing Regulation (EC) No. 1782/2003; OJEU; Publications Office of the European Union: Luxembourg, 2009.

89. European Commission. The Future of Food and Farming. Communication from the Commission to the European Parliament, the Council, the European Economic and Social Committee and the Committee of the Regions. COM (2017) 713 Final; OJEU; Publications Office of the European Union: Luxembourg, 2017.

90. García, T.; Folkeson, C. The new delivery model of the CAP: Some relevant issues. Econ. Agrar. Recur. Nat. 2020, 20, 147-165.

91. McEldowney, J.; Kelly, P. CAP strategic planning: Operational perspectives. Eur. Parliam. Res. Serv. 2019. Available online: https:/ / www.europarl.europa.eu/thinktank/en/document.html?reference=EPRS_IDA(2019)640139 (accessed on 2 April 2021).

92. Kiryluk-Dryjska, E.; Baer-Nawrocka, A. Reforms of the Common Agricultural Policy of the EU: Expected results and their social acceptance. J. Policy Model. 2019, 41, 607-622. [CrossRef]

93. Matthews, A. What Will the European Parliament Elections Mean for CAP Reform? Cap Reform Blog, 2019. Available online: http:/ / capreform.eu/what-will-the-european-parliament-elections-mean-for-cap-reform/ (accessed on 2 April 2021).

94. Cejudo, E. Los desequilibrios territoriales de la PAC. Cuad. Geogr. 2000, 30, 143-163.

95. Lamo de Espinosa, J.; Champourcin, M. Agricultura española en perspectiva. Papeles Econ. Esp. 2008, 117, 2-13.

96. Anderson, J.E.; Neary, J.P. A New Approach to Evaluating Trade Policy. Rev. Econ. Stud. 1996, 64, 107-125. [CrossRef]

97. Anderson, J.E.; Neary, J.P. Measuring the Trade Restrictiveness of Trade Policy. World Bank Econ. Rev. 1994, 8, 151-170. [CrossRef] 